include art-related posts. "We are starting to see a few positions for hybrid art-science professionals, and I believe this will continue to grow," says Malina. Nadarajan notes that Google and IBM are hiring graduates with design backgrounds for their research and development teams; and companies such as $3 \mathrm{M}$ and Proctor \& Gamble have a steady demand for those skills in their efforts to develop innovative materials.

Neuroscientist Siddharth Ramakrishnan is convinced that his work - which included an interactive exhibit focused on the Hox genes that define body regions in all animals - proved beneficial during his job search last year. "My art collaborations helped me stand out rather than being just one of hundreds of other neuroscientists who had done successful postdocs," he says, noting that interviewers found his proposals for campus-based art-science salons intriguing. In October, he started a job as an assistant professor at the University of Puget Sound, a liberal-arts college in Tacoma, Washington.

\section{UNCERTAIN PATH}

Not all research institutions or scientist colleagues embrace art-science collaborations. "You have to be aware that you could possibly jeopardize your career," says Lotto. "Many universities don't know how to assess the output of collaborations and some even actively discourage them."

Steve Potter, a neuroscientist at Emory University in Atlanta, Georgia, agrees. For the past decade, he has worked with artists at SymbioticA, an art-science studio at the University of Western Australia in Perth. One project, called MEART, connected a robotic arm to a network of rat neurons cultured on a multi-electrode array, to study the essence of creativity. But even though his department supports his endeavours, Potter knows that some colleagues are less accepting. He advises young scientists eager to pursue dual interests to consider joining an art department. "The safest thing to do is join a department that is open-minded; often that is more likely to be an art department," he says.

Systems engineer Leila Madrone says that aspiring artist-scientists should not despair if they have to do their art on the side at first. "Sometimes my work and art interests merge and sometimes they separate. It's most important to work in a creative environment," she says. As an undergraduate in MIT's media lab, Madrone combined giant Tesla coils, which put out stunning arcs of high-voltage electricity, with robots to create an interactive musical performance. In 2006, she headed to NASA's Ames Research Center in Moffett Field, California, to join the Intelligent Robotics Group. There, she worked on GigaPan, a robotic panoramic image-capture system. Now she is one of about 25 engineers at Otherlab, an independent engineering lab

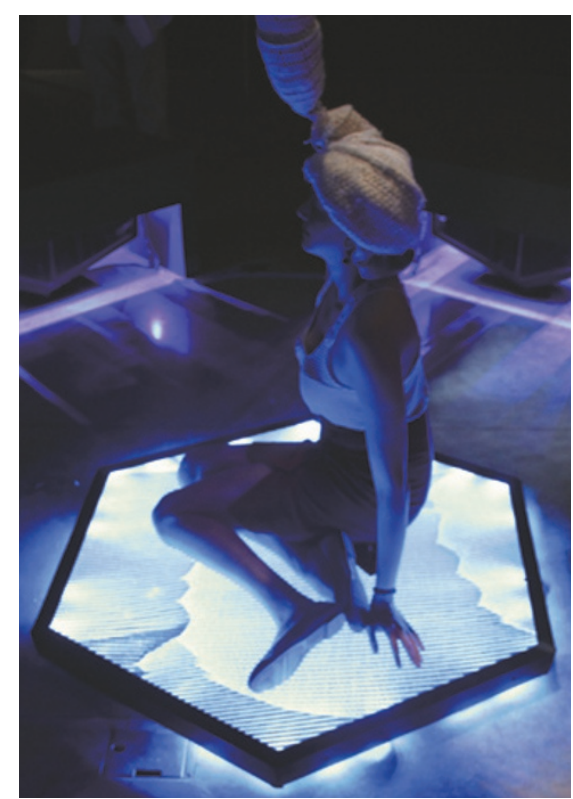

The 'Blue Morph' uses images and sounds from the metamorphosis of a caterpillar to a butterfly.

in San Francisco, California, that focuses on innovation in areas such as robotics, solar energy and electric vehicles. She does not have the security and benefits that she might get at a larger, established company, but there are perks. "I get to define what I am doing which is why, I think, people are attracted to this path," she says.

That path is not for everybody. "There is no recipe for a career in art-science," says Malina. Rather than looking for a formula or a well-trodden path, he says, students should identify specific career goals and develop the skills to achieve them, such as learning computer programming and design principles. And students might consider whether those hybrid skills are best suited to distinguish their art-science research aims, attract collaborators or simply provide a vehicle for artistic expression.

Agapakis is confident that she will continue to create her own opportunities. She has just finished a three-week stint helping to teach a graduate-level media design course focused on biotechnology at the Art Center College of Design in Pasadena, California. "For me," says Agapakis, "playing it safe is riskier because I wouldn't be pursuing the things I'm most passionate about."

\section{Virginia Gewin is a writer based in} Portland, Oregon.

\section{CORRECTION}

The Careers Brief 'Online journal club' (Nature 496, 261; 2013) wrongly gave the impression that the journal club mentioned was the first to go online; it was, in fact, the first to use the Journal Club Live platform.
NIH

\section{Postdoc pay rise}

Entry-level postdocs funded by the US National Institutes of Health would get a $7 \%$ stipend increase next year under President Barack Obama's proposed 2014 federal budget. New $\mathrm{PhD}$ recipients who receive the Ruth L. Kirschstein National Research Service Award (NRSA) would earn US\$42,000; those with a year or more of experience would receive a $4 \%$ rise over existing levels. "This is a huge step forward in recognizing the value of postdoctoral researchers' contributions," says Cathee Johnson Phillips, executive director of the National Postdoctoral Association (NPA) in Washington DC, which since 2001 has been advocating for the entry-level stipend to increase to $\$ 45,000$. The stipend rose by $1 \%$ in 2009 and 2010 , and by $2 \%$ in 2011 and 2012. A 2011 NPA survey found that half of US institutions base postdoctoral pay on the NRSA.

\section{FACULTY}

\section{Non-tenured jobs grow}

The number of full-time non-tenuretrack faculty members at US institutions grew by about $13 \%$ from 2007 to 2011 , compared with $11 \%$ for part-time faculty members, a report finds. Here's the News: The Annual Report on the Economic Status of the Profession, 2012-13, published on 8 April by the American Association of University Professors (AAUP) in Washington DC, also notes that more than one-fifth of assistant professors were off the tenure track in 2010-11. "Even among ranks that we would think of as tenure track, a significant proportion of faculty are not," says John Curtis, AAUP director of research and public policy.

\section{UNITED STATES}

\section{Chinese applications fall}

The number of applications to US graduate schools from students in China fell this year for the first time since 2006, when the US Council of Graduate Schools (CGS) in Washington DC first had sufficient sample sizes to keep track. An 8 April CGS report finds that total international applications to the United States grew by $1 \%$, the smallest rise in 8 years. Chinese applications fell by $5 \%$, after growth of $19 \%$ in 2012 and $21 \%$ in 2011. Services that help students to narrow down their choices may be a factor, says Rajika Bhandari, deputy vice-president for research and evaluation at the Institute of International Education in New York, as may the cost of US applications. 